\title{
Brazilian legislation and the school inclusion of individuals with communication disorders
}

\author{
Vanessa Boldarini de Godoy ${ }^{1}$ \\ https://orcid.org/0000-0001-5003-301X \\ Lia Netto Vaz Faiad ${ }^{1}$ \\ https://orcid.org/0000-0002-4388-3689 \\ Maria Aparecida Miranda de Paula Machado' \\ https://orcid.org/0000-0002-0359-2473 \\ Patrícia de Abreu Pinheiro Crenitte ${ }^{1}$ \\ https://orcid.org/0000-0003-3117-4575 \\ Dionísia Aparecida Cusin Lamônica ${ }^{1}$ \\ https://orcid.org/0000-0002-9381-0680 \\ Simone Rocha de Vasconcellos Hage ${ }^{1}$ \\ https://orcid.org/0000-0003-4790-6937
}

Faculdade de Odontologia de Bauru da Universidade de São Paulo FOB/USP, Departamento de Fonoaudiologia, Programa de Pós-Graduação em Fonoaudiologia, Bauru, São Paulo, Brasil.

Conflict of interests: Nonexistent

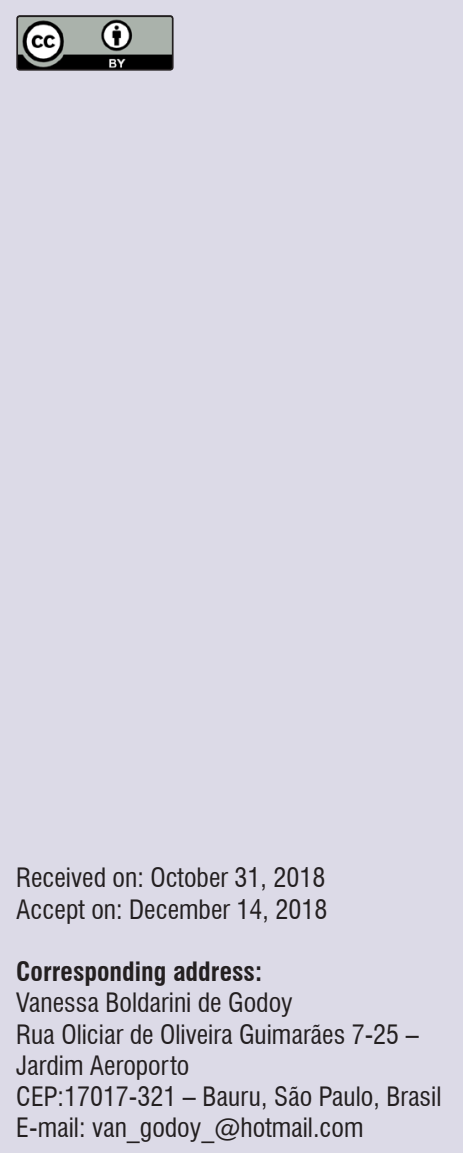

\section{ABSTRACT}

Objective: to verify if the current Brazilian Legislation assures the effective school inclusion of individuals with communication disorders.

Methods: the present study is an integrative review. Legislation related to the topic was searched on public databases, such as the website of the Planalto Palace (Brazilian Federal government headquarters), the website of the Culture and Education Ministry (Ministério de Educação e Cultura - MEC) the website of the National Education Council from Federal Government. Brazilian laws, ordinances and guidelines regarding special education of individuals with autism, intellectual disability, hearing impairment and dyslexia were consulted, since the descriptor "Communication Disorders" did not show any results.

Results: twenty-one (21) identified norms met the inclusion criteria. Among these, thirteen (13) address disabilities in a generalized manner. The other eight (8) regulations are specific in relation to autism, intellectual disability, hearing impairment and dyslexia.

Conclusion: despite the significant number of norms, the current Brazilian legislation does not allow for real school inclusion. Individuals with communication disorders do not have a specific legislation that could guide the peculiarities of each disorder, as well as their special educational needs. Thus, it was concluded that these individuals need legal support respecting their specificities, to allow their effective school inclusion.

Keywords: Communication Disorders. Legislation as Topic. Mainstreaming (Education) 


\section{INTRODUCTION}

Communication is the means through which the individual receives and expresses the language and it is fundamental for socialization and integration in the community'.

Mankind presents a pattern of development for verbal communication, which changes according to the language abilities and speech acquisition in all languages. Authors have reported that human communication should be considered a complex system that involves many different dimensions, rather than only the biological domain, such as body language, writing and verbal communication ${ }^{2}$.

Therefore, the etiology of communication disorders may involve several factors: organic, intellectual/ cognitive and emotional ones (related to family structure), with frequent inter-relation between all these factors ${ }^{3}$.

According to the American Speech Language and Hearing Association (Asha), communication disorders may be defined as impairments in the ability to receive and/or process a symbolic system, which may be noticed in hearing (sensitivity, function, processing and physiology); language (form, content and communicative function); and speech processes (articulation, voice and fluency). The disorders may have variable degrees of severity; they may be developmental or acquired; may lead to primary (diseases of primary or idiopathic manifestation) or secondary deficits (diseases of secondary manifestation, resulting from a greater expression), and they may also occur in isolation or combined ${ }^{4}$.

The impact of communication disorders on the individuals themselves or their family are hardly measured, since they have direct impact on the social, academic and occupational life of the individual. Therefore, communication disorders should be acknowledged as important public health issues".

According to the National Institute on Deafness and Other Communication Disorders (NIDCD-USA) ${ }^{5}$, of the Department of Health and Human Services of the USA, approximately one in each twelve (7.7\%) American children aged three to 17 years old presented an alteration in voice, speech, language or swallowing in the last 12 months. Among these children, 34\% in the age range 3 to 10 years old have multiple communication disorders, while $25.4 \%$ of children aged 11 to 17 years old present this disorder. The prevalence of communication disorders is higher in children aged three to six years $(11 \%)$, when compared to children from seven to ten years $(9.3 \%)$ and 11 to 17 years (4.9\%). Boys aged 3 to 17 years old were more likely to have a communication disorder than girls (9.6\% compared to $5.7 \%)^{5}$.

Data from the same American Institute ${ }^{5}$ revealed that $5 \%$ of children aged 3 to 17 years old had presented speech disorder in the last 12 months, and 3.3\% of children in the same age range presented some language disorder. The prevalence of speech disorders (naming, articulation or phonological disorders) in younger children was 8 to $9 \%$. Around the first school year, nearly $5 \%$ of children presented speech disorders, including some type of disfluency and dysarthria. Most of these speech disorders are of unknown origin 5 .

In Brazil, no statistical data were found concerning the prevalence of communication disorders. However, it is believed that, alike the significant percentages observed in a developed country as the USA, the same might occur in Brazil, maybe with even greater numbers.

The public policies for universal access to fundamental education do not seem to have assured the diagnosis and treatment for the effective inclusion in education for all children with communication disorders.

In this way, this study is justified by the scarce scientific literature on the subject in Brazil and its worldwide importance. Thus, the objective was to verify if the current Brazilian legislation assures school inclusion of individuals with communication disorders.

\section{METHODS}

This was an integrative review about the current legislation in the country related to the school inclusion of children with special educational needs, which aimed to analyze the norms adopted for the protection of children with communication disorders.

According to the literature, the five steps required to conduct an integrative review were followed. The first stage was the definition of the research subject; then, on the second stage, the criteria for inclusion and exclusion of regulations were established, according to the proposed theme. Following, on the third stage, the information to be extracted from the selected texts was defined; the fourth stage comprised evaluation of the included, and finally, the fifth stage included synthesis of the knowledge.

The guiding question was: Does the current Brazilian legislation assure the effective school inclusion of individuals with communication disorders?

The pertinent legislation was searched on the public databases of the Planalto Palace (Brazilian 
Federal government headquarters) website: http:// www.planalto.gov.br/; the Culture and Education Ministry (Ministério de Educação e Cultura - MEC) website: https://www.mec.gov.br/; and the website of the National Council of Education/MEC from federal government: http://portal.mec.gov.br/conselhonacional-de-educacao/, retrieving only norms addressing the Autism Spectrum Disorder, Intellectual Disability (Intellectual Development Disorder), Hearing Impairment and Dyslexia (within the context of Specific Learning Disorder).

Thus, the Brazilian laws, ordinances and guidelines related to these disorders were consulted and selected for the study.

The selection comprised the reading of the norm synopsis, its contents, and then the reading of the full text. Norms that did not address the guiding question were excluded, while the inclusion criteria encompassed the Salamanca Statement $(1994)^{6}$ because of the importance of this guideline on the inclusion of people with special educational needs in regular education, until the first semester of 2018.

The following data were extracted from each norm: website, year, norm title, synopsis and protected right.

The final sample consisted of 21 norms. The analysis and synthesis of extracted data were carried out descriptively, allowing observation, counting, description and classification of data, to gather the Brazilian legislation on the subject explored in this review.

\begin{tabular}{|c|c|c|c|c|}
\hline WEBSITE & YEAR & NORM & SYNOPSYS & RIGHT ASSURED \\
\hline MEC & 1994 & $\begin{array}{l}\text { Salamanca Statement } \\
\text { (6) }\end{array}$ & $\begin{array}{l}\text { Standards of the United Nations to promote equal } \\
\text { opportunities to people with special needs, A/ } \\
\text { RES/48/96, Resolution of the United Nations adopted } \\
\text { in General Assembly. }\end{array}$ & $\begin{array}{l}\text { Principles, Policies and Practices in the Field of Special } \\
\text { Education Needs. }\end{array}$ \\
\hline PLANALTO & 1996 & $\begin{array}{l}\text { Law of Basic Tenets } \\
\text { and Guidelines of } \\
\text { Brazilian Education n. } \\
9394(7) \\
\end{array}$ & $\begin{array}{l}\text { Establishes the basic tenets and guidelines of the } \\
\text { national education. }\end{array}$ & Protection of Right to Education for all. \\
\hline CNE/MEC & 1996 & $\begin{array}{l}\text { Deliberation CEE n. } \\
\quad 11 / 96(16)\end{array}$ & $\begin{array}{l}\text { Presents the means for evaluation of dyslexic } \\
\text { students. }\end{array}$ & $\begin{array}{l}\text { The final result of the evaluation made at the school, } \\
\text { according to its rules, should reflect the overall performance } \\
\text { of the student during the school year, in the collection of } \\
\text { curricular components. }\end{array}$ \\
\hline CNE/MEC & 1998 & $\begin{array}{l}\text { Indication CEE n. } 5 / 98 \\
\text { (32) }\end{array}$ & Addresses the basic education. & $\begin{array}{l}\text { The school education comprises the integral and functional } \\
\text { training of schoolchildren, i.e. the acquisition of abilities } \\
\text { of all type: cognitive, motor, affective, autonomy, personal } \\
\text { balance, inter-personal relationship and social interaction. } \\
\text { The schoolchildren do not learn in the same manner nor } \\
\text { at the same timing. What they may learn in a given stage } \\
\text { depends on their maturity level, previous knowledges, type } \\
\text { of intelligence, more verbal, more logic or more spatial. }\end{array}$ \\
\hline PLANALTO & 1999 & Decree 3298 (8) & $\begin{array}{l}\text { Regulates the Law n. 7853, of October 24th1989, } \\
\text { presenting the National Policy for Integration of } \\
\text { People with Disabilities, consolidating the norms for } \\
\text { protection, and presents other ordinances. }\end{array}$ & Equal opportunities of access to Education of the Disabled. \\
\hline CNE/MEC & 2001 & $\begin{array}{l}\text { National Guidelines for } \\
\text { the Special Education } \\
\text { in Basic Education } \\
\text { RESOLUTION CNE/CEB } \\
\text { N. } 2 \text { AND } 17 \text { (11) }\end{array}$ & $\begin{array}{l}\text { Establishes effective and adequate policies to } \\
\text { establish the special education. }\end{array}$ & $\begin{array}{l}\text { Proposal for the Inclusion of Items or Disciplines concerning } \\
\text { children with special educational needs in the curricula of } \\
\text { elementary and high school. }\end{array}$ \\
\hline PLANALTO & 2001 & Decree n. 3956 (9) & $\begin{array}{l}\text { Presents the Inter-American Convention for } \\
\text { Elimination of All Means of Discrimination Against } \\
\text { People with Disabilities. }\end{array}$ & $\begin{array}{l}\text { Restates that people with disabilities have the same human } \\
\text { right and fundamental freedoms as other people, and } \\
\text { these rights, including the right of not being subject to } \\
\text { discrimination based on the disability, come from the dignity } \\
\text { and equity that are inherent to all human beings. }\end{array}$ \\
\hline PLANALTO & 2001 & Law n. 10172 (33) & National Education Plan. & $\begin{array}{l}\text { The special education is targeted to people with special } \\
\text { needs in the field of learning, originated from physical, } \\
\text { sensorial, mental or multiple disabilities, or characteristics } \\
\text { as high abilities or gifted or talented students. }\end{array}$ \\
\hline PLANALTO & 2002 & Law n. 10436 (17) & $\begin{array}{l}\text { Presents the Brazilian Sign Language - Libras and } \\
\text { other ordinances }\end{array}$ & $\begin{array}{l}\text { The public power in general,companies and third parties } \\
\text { should assure institutional manners to support the use } \\
\text { and diffusion of the Brazilian Sign Language - Libras as an } \\
\text { objective and currently used communication means of deaf } \\
\text { communities in Brazil. }\end{array}$ \\
\hline
\end{tabular}




\begin{tabular}{|c|c|c|c|c|}
\hline WEBSITE & YEAR & NORM & SYNOPSYS & RIGHT ASSURED \\
\hline MEC & 2002 & $\begin{array}{l}\text { Hospital class and } \\
\text { home specialized } \\
\text { pedagogical } \\
\text { attendance - strategies } \\
\text { and orientation (34) }\end{array}$ & $\begin{array}{l}\text { The right to education is expressed as a right to } \\
\text { learning and schooling, which is fundamentally and } \\
\text { primarily translated as the access to basic education } \\
\text { school, considered mandatory, according to the } \\
\text { Brazilian Federal Constitution. }\end{array}$ & $\begin{array}{l}\text { The article } 214 \text { of the Federal Constitution also states that } \\
\text { the public power actions should allow the universalization of } \\
\text { school attendance. }\end{array}$ \\
\hline MEC & 2004 & $\begin{array}{l}\text { Inclusive Education } \\
\text { Program: right to } \\
\text { diversity, philosophical } \\
\text { basis (35) }\end{array}$ & $\begin{array}{l}\text { Assures to all individuals equal conditions for the } \\
\text { access and permanence in the school, without } \\
\text { any type of discrimination, a principle that is in our } \\
\text { Constitution since 1988, yet still did not became } \\
\text { reality for thousands of children and youngsters; } \\
\text { girls and adolescents presenting special educational } \\
\text { needs, related or not to disabilities. }\end{array}$ & $\begin{array}{l}\text { The idea of an inclusive society is based on a philosophy } \\
\text { that recognizes and values the diversity, as inherent } \\
\text { characteristic to the constitution of any society. }\end{array}$ \\
\hline PLANALTO & 2004 & Law n. 10845 (37) & $\begin{array}{l}\text { Establishes the Complementary Program for the } \\
\text { Specialized Educational Attendance to People with } \\
\text { Disabilities and presents other ordinances. }\end{array}$ & $\begin{array}{l}\text { To assure the universalization of specialized attendance to } \\
\text { students with disabilities whose situation does not allow } \\
\text { their integration in common classes of regular teaching. }\end{array}$ \\
\hline PLANALTO & 2005 & Decree 5626 (18) & $\begin{array}{l}\text { Regulates the Law n. } 10436 \text { of April 24th2002, which } \\
\text { presents the Brazilian Sign Language - Libras, and } \\
\text { article } 18 \text { of Law n. } 10098 \text { of December 19th2000. }\end{array}$ & $\begin{array}{l}\text { This decree considers as deaf any person who, due to } \\
\text { the hearing impairment, understands and interacts with } \\
\text { the world by visual experiences, manifesting their culture } \\
\text { especially by the Brazilian Sign Language - Libras. }\end{array}$ \\
\hline PLANALTO & 2007 & Ordinance n. 948 (36) & $\begin{array}{l}\text { National Policy of Special Education from the } \\
\text { Standpoint of Inclusive Education }\end{array}$ & $\begin{array}{l}\text { Transverse special education, from elementary to superior } \\
\text { education }\end{array}$ \\
\hline MEC & 2009 & Resolution n. 4 (38) & $\begin{array}{l}\text { Establishes Operational Guidelines for Specialized } \\
\text { Educational Care (AEE) in Basic Education, modality } \\
\text { Special Education. }\end{array}$ & $\begin{array}{l}\text { The complementary or supplementary function of the AEE is } \\
\text { the school training by the availability of services, accessibility } \\
\text { resources and strategies to eliminate the barriers for their } \\
\text { full participation in society and development of learning. }\end{array}$ \\
\hline PLANALTO & 2009 & Decree 6949 (39) & $\begin{array}{l}\text { Publishes the International Convention on the Rights } \\
\text { of People with Disabilities and its Facultative Protocol, } \\
\text { signed in New York on March 30th2007. }\end{array}$ & $\begin{array}{l}\text { The proposal of this convention is to promote, protect and } \\
\text { assure the full and equal exercise of all human rights and } \\
\text { fundamental freedoms for all people with disabilities and } \\
\text { promote the respect to their inherent dignity. }\end{array}$ \\
\hline MEC & 2011 & $\begin{array}{c}\text { Technical note } \\
\text { 06/2011- MEC/SEESP/ } \\
\text { GAB (26) }\end{array}$ & Evaluation of students with intellectual disability. & $\begin{array}{l}\text { Presents the evaluation of students with intellectual disability. } \\
\text { Establishes that teachers are in charge of the specialized } \\
\text { educational attendance and identification of educational } \\
\text { specificities of each student in an articulated manner with } \\
\text { the regular classroom. }\end{array}$ \\
\hline PLANALTO & 2012 & Law n. 2764 (27) & $\begin{array}{l}\text { Establishes the National Policy of Protection of the } \\
\text { Rights of People with Autism Spectrum Disorder; and } \\
\text { alters the 3rd paragraph of article } 98 \text { of Law n. } 8112 \\
\text { of December 11th1990. }\end{array}$ & $\begin{array}{l}\text { This Law establishes the National Policy for Protection } \\
\text { of Rights of People with Autism Spectrum Disorder and } \\
\text { establishes guidelines for their accomplishment. }\end{array}$ \\
\hline PLANALTO & 2013 & $\begin{array}{l}\text { Ordinance n. } 1274 \\
\qquad(19)\end{array}$ & $\begin{array}{l}\text { Includes the Personal Frequency Modulation System } \\
\text { (FM) in the Table of Procedures, Drugs, Ortheses, } \\
\text { Prostheses and Special Materials (OPM) of the } \\
\text { Brazilian Public Health System. }\end{array}$ & $\begin{array}{l}\text { All students of elementary or high school with hearing } \\
\text { impairment, using bilateral } \mathrm{HA} \text { or } \mathrm{Cl} \text {, may be fitted with the } \\
\text { bilateral FM system (one receptor for each } \mathrm{HA} \text { and/or } \mathrm{Cl} \text { ). }\end{array}$ \\
\hline PLANALTO & 2014 & Decree 8368 (28) & $\begin{array}{l}\text { Regulates the Law n. 12764, of December } \\
\text { 27th2012, which establishes the National Policy of } \\
\text { Protection of the Rights of Individuals with Autism } \\
\text { Spectrum Disorder }\end{array}$ & $\begin{array}{l}\text { People with autism spectrum disorder are entitled to } \\
\text { all rights and obligations foreseen in the International } \\
\text { Convention about the Rights of People with Disabilities } \\
\text { and its Facultative Protocol, published by Decree } n \text {. } 6949 \\
\text { of August 25th2009, and the laws related to people with } \\
\text { disabilities. }\end{array}$ \\
\hline PLANALTO & 2015 & Law n. 13146 (40) & $\begin{array}{l}\text { Establishes the Brazilian Law of Inclusion of People } \\
\text { with Disabilities (Statute of People with Disabilities). }\end{array}$ & $\begin{array}{l}\text { It aims to assure and promote, in equal conditions, the } \\
\text { exercise of rights and fundamental freedoms for people with } \\
\text { disabilities, aiming at their social inclusion and citizenship. }\end{array}$ \\
\hline PLANALTO & 2015 & Law n. 13146 (40) & $\begin{array}{l}\text { Establishes the Brazilian Law of Inclusion of People } \\
\text { with Disabilities (Statute of People with Disabilities). }\end{array}$ & $\begin{array}{l}\text { It aims to assure and promote, in equal conditions, the } \\
\text { exercise of rights and fundamental freedoms for people with } \\
\text { disabilities, aiming at their social inclusion and citizenship. }\end{array}$ \\
\hline
\end{tabular}

Figure 1. Brazilian legislation and school inclusion 


\section{LITERATURE REVIEW}

The searches on the public and official databases retrieved 21 norms that contributed to the guiding question of the present research, i.e., the inclusive education in Brazil.

The study extracted information about the rights and individuals protected by the current regulations in order to identify the target population of that legal ordinance.

Among the laws found, the initial milestone was the Salamanca Statement in 19946, which proposes the inclusion of children, youngsters and adults with special educational needs within the regular education system as a central and guiding question, with significant repercussion on the Brazilian legislation.

The Salamanca Statement was designed at the World Conference on Special Educational Needs, promoted by the Spanish Government in collaboration with Unesco ${ }^{6}$.

Thereafter, the Law of Basic Tenets and Guidelines of Brazilian Education (n. 9394/96) ${ }^{7}$ was published, structuring a new idea of education. Article n. 58 of this law addresses the special education as a modality of school education of the regular school network, considered the first step in Brazilian legislation.

The Decree 3298/998 and the National Guidelines for Special Education in Basic Education strengthened the basis, until then, initially structured, regarding the Inclusive Education.

The principles of the Inter-American Convention of $2001^{9}$ restated the Human Rights Declaration of $1948^{10}$, especially addressing the population with disabilities, focusing on the absolute respect to the dignity and individuality; independence and autonomy for full and broad participation in the community life.

The article 5 of Resolution CNE/CEB $n$. $02 / 2011^{11}$ considered as students with special educational needs those who present, during the educational process:

I - marked learning difficulties or limitations in development that impair them to follow the curriculum activities, including two groups:

a) Those not related to a specific organic cause;

b) Those related to the conditions, dysfunctions, limitations or deficiencies;

II - communication and signaling difficulties differentiating from the other students, requiring the utilization of applicable languages and codes;

III - high abilities/gifted students, markedly easy learning that lead them to rapidly learn concepts, procedures and attitudes ${ }^{11}$.
Initially, the study searched for papers that related regulations on school inclusion and communication disorders, however, no paper was found. Therefore, it was necessary to change and the searches were then conducted in databases using the Planalto Palace the Ministry of Education and Culture and the National Education Council websites, to identify the norms that address and highlight developmental disorders that might impair the communication to some extent.

These disorders include the Autism Spectrum Disorder (DSM V - Diagnosticand Statistical Manual of Mental Disorders) ${ }^{12}$, which commonly include the following characteristics: persistent deficits in communication and social interaction in multiple contexts; restricted and repetitive patterns of behavior, interests or activities; inflexible adherence to routines; rigid patterns of thoughts; hyper or hypoactivity to sensory stimuli.

According to the $\mathrm{DSMV}^{12}$, published in 2013 by the American Psychiatric Association, in recent years, the reported occurrence of Autism Spectrum Disorder in the United States and other countries reached $1 \%$ of the population, with similar estimates in samples of adults. It is still unclear whether higher rates indicate an expansion of the diagnostic criteria of DSM-IV to include sub-borderline cases, increased awareness, differences in study methodology or actual increase in the frequency of the disorder.

In the context of Intellectual Disability (Intellectual Development Disorder - DSMV), there is a concomitant occurrence of significant limitations in intellectual functioning and delays in at least three fields of adaptive behavior, expressed in conceptual, social and practical skills, which include daily activities of the individual and adaptation to social demands. The main characteristics are: deficits in reasoning functions, problem solving, planning; limitations in activities such as communication, social participation and independent living; deficits in adaptive functioning involving three domains: practical, conceptual and social ${ }^{12}$.

The American Psychiatry Association estimates a general prevalence of intellectual disability in the entire population of about $1 \%$, with variations according to age. The prevalence of severe intellectual disability is about 6 in each $1,000^{12}$.

In 2013, the IBGE (Brazilian Institute of Geography and Statistics) ${ }^{13}$ in partnership with the Ministry of Health conducted a National Health Research (PNS) and reported that $0.8 \%$ of the population has some type of intellectual disability (Intellectual Development 
Disorder), and the majority (0.5\%) was born with the limitations. Among people with intellectual disabilities, more than half $(54.8 \%)$ have an intense or very intense limitation and about $30 \%$ attend some health rehabilitation service ${ }^{13}$.

Another disorder addressed in the legislation is the Hearing Impairment, defined as hearing loss due to conductive and/or sensorineural disorder (H90) by the International Statistical Classification of Diseases and Related Health Problems (ICD-10). Hearing impairment may be partial or total, unilateral or bilateral; it may be conductive, with interference in sound transmission from the external auditory canal to the inner ear (cochlea); or sensorineural, which affects the reception of sound by lesion of ciliated cells of the cochlea or auditory nerve. Hearing impairment may also be mixed.

The American Speech Language and Hearing Association ${ }^{4}$ reported that children with hearing impairment present more difficulties in learning vocabulary, grammar, idiosyncratic expressions and other aspects of verbal communication compared to normalhearing children.

In 2005, according to the World Health Organization (WHO), there were 278 million people worldwide with hearing impairment, with prevalence ranging from $2.1 \%$ to $8.8 \%$ of incapacitating hearing loss in developing countries $^{14}$.

The National Institute on Deafness and Other Communication Disorders (NIDCD) ${ }^{5}$, of the Department of Health and Human Services of the USA reported that two to three in every 1,000 children in that country are born with some degree of detectable hearing loss in one or both ears, and more than $90 \%$ of congenitally deaf children have normal-hearing parents. In addition, five in every six children experience ear infection (otitis media) around the third year of life.

In Brazil, according to the IBGE, people with hearing impairment represent $1.1 \%$ of the Brazilian population, and this type of disability was the only with statistically different results according to ethnicity, being more common in white people (1.4\%) than in blacks $(0.9 \%)$. About $0.9 \%$ of Brazilians became deaf due to some illness or accident, and $0.2 \%$ were congenitally deaf. Among the total number of individuals with hearing impairment, $21 \%$ have intense or very intense limitations, affecting the daily life activities ${ }^{13}$.

Finally, there is dyslexia, which fits within the broad spectrum of Specific Learning Disorder. According to the DSM V, this disorder is characterized by difficulties in learning and utilization of academic skills, indicated by the presence of at least one of the symptoms that persisted for at least six months, despite the offer of interventions to address these difficulties ${ }^{12}$.

The symptoms may include inaccurate word reading or slow with effort; difficulty to understand the meaning of reading; spelling difficulties; difficulties with written expression; difficulties in mastering the numerical sense, numerical facts or calculation; and reasoning difficulties ${ }^{12}$.

The affected academic abilities are substantially and quantitatively below the expected for the chronological age of the individual, with significant interference in the academic, professional or daily activities ${ }^{12}$.

Within this disorder, there is specific impairment in reading, characterized by problems in the accurate or fluent word recognition, decoding problems and spelling difficulties (DSM V) ${ }^{12}$. This disorder is known worldwide as dyslexia.

According to the Brazilian Association of Dyslexia $(A B D)$, investigations conducted in several countries estimate that $5 \%$ to $17 \%$ of the world population is dyslexic ${ }^{15}$.

Considering the present results, it is observed that 14 of the current norms address the school inclusion in a generalized manner, not describing the specificities of each disorder or disability. Such norms present the right to school inclusion of individuals only by inserting them in the school environment, not providing essential subsidies for their effective inclusion; thus, the functionality is dependent on the legal or educational interpretations.

Regarding the specific norms, the first found was Deliberation CEE n. 11/96, which reports about dyslexia. This norm only addresses the evaluation of this individual, not addressing the complexity of learning disorder, nor providing enablers for school inclusion ${ }^{16}$.

Professionals specialized in inclusive education report that individuals with dyslexia need greater stimulation and motivation to practice activities that develop their expressive or receptive language. They inform that the teacher may help the student to imagine the text subject from the title when reading; relate the story to subjects in which they are interested; encourage reading activities; ask questions and explain what was read; refer to specialized evaluation as soon as possible ${ }^{15}$.

Within the complexity of hearing impairment, four regulations were found, namely: Federal Law $\mathrm{n}$. $10436 / 2002^{17}$ and its regulation by Federal Decree $5626 / 2005^{18}$. These norms are very specific, since they 
only address the implementation of the Brazilian Sign Language (LIBRAS) in schools. Thus, all individuals with hearing loss, regardless of the degree, are categorized in the same manner and induced to use this option of alternative communication, disregarding the individualities and potentialities of each individual.

Thus, students who do not fall within this communication category may appeal to Ordinance $n$. $1274 / 2013^{19}$, which addresses the use of Personal Frequency Modulation System. Also known as FM System, this device has the main function of eliminating the effect of distance. It takes the teacher's voice closer to the child's ear, making it stand out from within the noise and echo. It is an extremely important system for students who use individual hearing aids (HA) or cochlear implants $(\mathrm{Cl})$.

Regarding the $\mathrm{HA}$ and $\mathrm{Cl}$, no regulations were found specifically related to school inclusion, yet it is known that individuals with hearing impairment have the right to use these devices for hearing rehabilitation ${ }^{20-23}$.

It is important to mention that the Federal Law $12303 / 2010^{24}$ and Ordinance n. 1328/SAS/MS of $2012^{25}$ established as mandatory the free examination of evoked otoacoustic emissions of children born in all hospitals and maternities, thus facilitating the early detection of hearing impairment. This detection is fundamental to allow early intervention in the first year of life, allowing the development of oral language at the appropriate age.

With regard to Intellectual Disability (Intellectual Development Disorder), the search retrieved only one Technical Note 06/2011-MEC/SEESP/GAB, which addresses the evaluation of students with this disorder $^{26}$. Alike dyslexia, these individuals are not legally supported concerning their special needs. It is evident that the law only demands the enrollment of students, yet their difficulties and peculiarities are not considered in a specialized manner as needed.

Thus, the Technical Note is inconsistent, since the evaluation of these students can be made in a differentiated manner, yet the teaching strategies, which are common to all, do not provide effective learning, since they do not consider the educational needs of the individual with intellectual disability.

Finally, the Federal Law n. 12764/1227 regulated by Federal Decree $8368 / 14^{28}$ establishes the National Policy for the Protection of Rights of People with Autism Spectrum Disorder. Again, it is observed that the insertion of students with this disorder is guaranteed by the current legislation. However, there are no effective public policies to structure and adapt the environment to receive these children and enable the learning that is desired by the family.

It is pertinent to correlate the Brazilian Legislation with the law of a highly developed country in educational terms.

Only concerning the learning disorders, the United States presents the section 504 of the Rehabilitation Act (1998), which includes hundreds of recommendations to be followed by all public schools in the country ${ }^{29}$.

Some of them are: preferential student seat on the front; shorter class periods, with longer intervals; instructions given in small groups; matching written and oral instructions; reduced amount of homework; allow consultation of books during school tests; offering of oral examinations; allowance of extra time on tests; avoidance of oral reading, especially in students with dyslexia; allowance of utilization of calculator (version/ translation of the authors) ${ }^{30}$.

In addition, there are two sectors within the Department of Education of that country designated to oversee these laws, namely the Office for Civil Rights (OCR) and the Office of Special Education and Rehabilitative Services (OSERS) ${ }^{29}$.

In Spain, there is also a specific law for people with learning difficulties (Organic Law 02/2006). The article 79 of Boletín Oficial del Estado - Legislación Consalidada presents the measures for schooling and attention to these individuals ${ }^{31}$.

In this regard, it seems unacceptable that Brazilian legislation does not yet address the specificities of each disorder/disability and is presented in such generalized manner. The communication disorders, which include many important disorders in the development of any child, are still neglected by our national legislation.

Within this context, school education should aim at the integral and functional formation of learners, i.e. the acquisition of abilities of all types: motor, autonomy, cognitive, affective, personal balance, personal interrelationship and social inclusion ${ }^{32}$.

It is evident that our legal system has numerous basic/generic laws on the school inclusion of disabled individuals, as seen by the Law n. 10172/2001 ${ }^{33}$, Hospital class and home specialized pedagogical attendance $^{34}$, Inclusive Education Program: right to diversity, philosophical basis ${ }^{35}$ and Ordinance n. 948/0736. Such norms do not address the specific aspects of learning into each disability; rather, they only provide theoretical reflections on the subject and about the transversal teaching ${ }^{36}$. 
The Law $10845 / 2004^{37}$ assures the universalization of specialized care of students with disabilities whose situation does not allow integration into common classes in regular schools. The Resolution n. 4/200938 presents the operational guidelines for specialized care.

This Service has the complementary or supplementary function of student training by the availability of services, accessibility resources and strategies to favor their learning ${ }^{36,37}$. The idea of this service is to provide a starting point for a specific approach for disabled individuals and their specificities.

In 2007, the International Convention on the Rights of People with Disabilities was held in New York. In 2009, this Convention was published by Decree n. 6949. The purpose of this Convention was to promote, protect and assure the full and equal access to all human rights and fundamental freedoms for all people with disabilities, and to promote respect for their inherent dignity ${ }^{39}$.

Finally, the last official document found in Brazilian law on the school inclusion of the disabled was Law n. $13146 / 2015^{40}$, aiming to assure and promote, with equal conditions, the exercise of fundamental rights and freedom by people with disabilities, aiming at their social inclusion and citizenship.

Once again, a law created to include the disabled in the school only assured the right, yet it did not promote effective inclusion.

The special educational needs should be carefully understood so that students are evaluated in all their aspects (academic, psychological, physical, environmental, social, etc.) and, when necessary, specific curricular adaptations and interventions to guarantee the learning, performed.

For individuals with any special educational needs, the environment should be structured and adapted to the different existing demands. This includes the physical structure, specific training of teachers, insertion of specialized professionals in the multidisciplinary team, school organization, adaptations in teaching methodology, use of differentiated strategies, specialized administrative management and promotion of social awareness, in general, for effective inclusion.

\section{CONCLUSION}

At the end of the study, it was possible to verify that, despite the significant number of norms, the current legislation has significant gaps, is general, and thus, does not allow for real school inclusion.

Even though there are more general or universal guidelines and norms, individuals diagnosed with dysphonia, fluency disorders, specific language disorder, phonological disorder, apraxia, auditory processing disorder, cleft lip and palate, among other disorders, i.e., individuals who also present communication disorders, are totally helpless from a legal standpoint.

In particular, communication disorders do not have a specific legislation that could guide the peculiarities of each situation, as well as the special educational needs of each case. Thus, it was concluded that these people need a more specific legal support to assure the effective school inclusion.

In the authors' opinion, the difficult task of structuring an inclusive educational system should not be limited only to education. The need for changes in the educational system should be met by the entire community and the public power. The school should have conditions to fulfill its specific role of promoting the learning of all schoolchildren.

Also, it seems difficult to make final considerations in a process that, despite some small evolutions, is still far from the ideal concept.

\section{REFERENCES}

1. Prates LPC, Martins VO. Distúrbios da fala e da linguagem na infância. Revista Médica de Minas Gerais. 2011;21 (4-supl):S54-S60.

2. Goulart BNG, Chiari BM. Prevalência de desordens de fala em escolares e fatores associados. Rev. Saúde Pública.2007;41 (5-supl):S726-S731.

3. Schirmer CR, Fontoura DR, Nunes ML. Distúrbios da aquisição da linguagem e da aprendizagem. J. Pediatr. 2004;80(2-supl):S95-S103.

4. ASHA: American Speech and Hearing Association. Meaning of Communication Disorders. [cited 2016Jun 29]. Available from: ajslp.pubs.asha.org

5. NIDCD-USA - National Institute on Deafness and Other Communication Disorders. [cited 2016 Mai 19 ] Available from: https://www.nidcd.nih.gov/health/ statistics/quick-statistics-voice-speech-language

6. Unesco, Declaração de Salamanca. Sobre Princípios, Políticas e Práticas na Área das Necessidades Educativas Especiais. Available from:http://portal.mec.gov.br/seesp/arquivos/pdf/ salamanca.pdf

7. Brasil, Lei de Diretrizes e Bases da Educação. Lei № 9.394/96, de 20 de Dezembro de 1996. Diário Oficial da União - Seção 1 - 23/12/1996, Página 27833, de 20 dez 1996. 
8. Brasil, Regulamenta a Lei no 7.853, de 24 de outubro de 1989 - Decreto 3.298 - Brasília - DF, 1998. Diário Oficial da União. 24 out 1989

9. Brasil, Promulga a Convenção Interamericana para a Eliminação de Todas as Formas de Discriminação contra as Pessoas Portadoras de Deficiência. Decreto 3.956-Brasília - DF, 2001. Diário Oficial da União 9 out 2001.

10. Assembléia Geral da ONU. "Declaração Universal dos Direitos Humanos". 217 (III) A. Paris, 1948. Available from: http://www.un.org/en/ universal-declaration-human-rights/

11. Brasil, Ministério da Educação. Conselho Nacional da Educação. Diretrizes Nacionais para a educação especial na educação básica CNE/CEB № 2 E 17 - Secretaria da Educação - MEC; SEESP, 2001. Diário Oficial da União, Brasília, 14 set 2001 Seção 1E, p. 39-40.

12. Nascimento MIC, Machado PH, Garcez RM, Pizzato R, Rosa SMM. Manual Diagnóstico Estatístico de Transtornos Mentais -DSM-5 [American Psychiatric Association, traduc.] Porto Alegre: Artmed 2014. $5 e d$.

13. IBGE, Instituto Brasileiro de Geografia e Estatística, Available from: https://sidra.ibge.gov.br/ tabela/5718

14. 14-WHO - World Health Organization. Prevention of deafness and hearing impairment. Available from: http://www.who.int/pbd/deafness/en/survey_ countries.gifen

15. Brandão MS. Comunicação Humana e seus Distúrbios: Formação e Capacitação de professores de Educação Física [dissertação]. Santa Maria (RS): Universidade Federal de Santa Maria; 2014.

16. Brasil, Ministério da Educação. Conselho Nacional da Educação. Deliberação CEE no 11 Secretaria da Educação - MEC; SEESP, 1996. Homologada por Res. SE de 27/12/96, publicado no DOE em 28/12/96, Seção I, pág. De 12. 11 dez de 1996.

17. Brasil, Dispõe sobre a Língua Brasileira de Sinais - Libras e dá outras providências. - LEI № 10.436-Brasília - DF, 2002. Diário Oficial da União publicado em 25 abr 2002.

18. Brasil, Regulamenta a Lei $n^{\circ} 10.436$, de 24 de abril de 2002- Decreto 5.626-Brasília - DF, 2005. Diário Oficial da União publicado em 23 dez 2005.

19. Brasil, Inclui o Procedimento de Sistema de Frequência Modulada Pessoal (FM) na Tabela de Procedimentos, Medicamentos, Órteses, Próteses e Materiais Especiais (OPM) do Sistema Único de Saúde. - Portaria № 1.274-Brasil - DF, 2013.

20. Brasil, Portaria no 589, de 08 de outubro de 2004. Brasília - DF, 2004

21. Brasil, Portaria no 2.776, de 18 de dezembro de 2014, Brasília - DF, 2014.

22. Brasil, Portaria no 18/SCTIE/MS, de 10 de junho de 2014, Brasília - DF, 2014.

23. Brasil, Portaria $n^{\circ} 2.157$, de 23 de dezembro de 2015, Brasília - DF, 2015.

24. Brasil, Dispõe sobre a obrigatoriedade de realização do exame denominado Emissões Otoacústicas Evocadas. Lei Federal 12.303, de 2 de agosto de 2010, Brasília - DF, 2010

25. Brasil, Portaria no 1.328/SAS/MS, de 3 de dezembro de 2012, Brasília - DF, 2012.

26. Brasil, Ministério da Educação. Nota Técnica 06. Brasília: MEC/SEESP, 2011.

27. Brasil, Institui a Política Nacional de Proteção dos Direitos da Pessoa com Transtorno do Espectro Autista. - Lei no 12.764-Brasília - DF, 2012.

28. Brasil, Regulamenta a Lei no 12.764 , de 27 de dezembro de 2012- Decreto 8368-Brasília - DF, 2014.

29. U.S. Department of Education, Protecting students with disabilities: Frequently asked questions about Section 504 and the education of children with disabilities. 2018. Acesso: 05/07/18. Disponível em: http://www.ed.gov

30. Courter MK. Just the facts. In: Here's how children learn speech and language. Indianapolis/ Indiana. Plural Publishing, 2011. p. 1-15.

31. Espanha, Ley Orgánica 2/2006, Boletín Oficial del Estado - Legislación Consalidada art. 79, 3mayo, de Educación, Espanha.

32. Brasil, Ministério da Educação. Conselho Nacional da Educação. Indicação CEE no 5 Secretaria da Educação - MEC; SEESP,1998. DOE em 23/09/98 Seção I Página 13/14 de 15 de abr 1998.

33. Brasil, Plano Nacional de Educação. - Lei no 10.172-Brasília - DF, 2001. Diário Oficial da União. Publicado em 10 jan 2001.

34. Brasil, Ministério da Educação. Classe hospitalar e atendimento pedagógico especializado domiciliar - estratégias e orientações. Brasília: MEC/SEESP, 2002.Disponível em: http://portal.mec.gov.br/ seesp/arquivos/pdf/livro9.pdf

35. Brasil, Ministério da Educação /SEESP. Programa Educação Inclusiva: direito à diversidade. Fundamentação Filosófica - Brasília: SEESP, 2004 
Disponível em: http://portal.mec.gov.br/seesp/ arquivos/pdf/fundamentacaofilosofica.pdf

36. Brasil, Política Nacional de Educação Especial na Perspectiva da Educação Inclusiva - Portaria no 948-Brasília - DF, 2007. Disponível em: http://peei. mec.gov.br/arquivos/politica_nacional_educacao_ especial.pdf

37. Brasil, Institui o Programa de Complementação ao Atendimento Educacional Especializado às Pessoas Portadoras de Deficiência, e dá outras providências - Lei no 10.845-Brasília - DF, 2004. Diário Oficial da União 08 mar 2004.

38. Brasil, Ministério da Educação. Resolução № 4. Institui Diretrizes Operacionais para o Atendimento Educacional Especializado na Educação Básica, modalidade Educação Especial. Brasília: MEC/ SEESP, 2009. Disponível em: http://portal.mec.gov. br/dmdocuments/rceb004_09.pdf

39. Brasil, Promulga a Convenção Internacional sobre os Direitos das Pessoas com Deficiência e seu Protocolo Facultativo, Nova York, 30 março 2007. - Decreto 6.949-Brasília - DF, 2009.

40. Brasil, Institui a Lei Brasileira de Inclusão da Pessoa com Deficiência (Estatuto da Pessoa com Deficiência). LEI № 13.146- Brasília - DF, 2015. 